Zeszyty Naukowe Szkoły Głównej Gospodarstwa Wiejskiego w Warszawie

Problemy Rolnictwa Światowego tom 18 (XXXIII), zeszyt 4, 2018: 370-381

DOI: $10.22630 /$ PRS.2018.18.4.126

Karolina Pawlak $^{1}$, Dawid Jabkowski ${ }^{2}$

Uniwersytet Przyrodniczy w Poznaniu

\title{
Przewagi komparatywne USA w eksporcie wybranych surowców roślinnych na Jednolity Rynek Europejski ${ }^{3}$
}

\section{Comparative Advantages of the US in the Export of Selected Plant Raw Materials to the Single European Market}

\begin{abstract}
Synopsis. Celem artykułu było zidentyfikowanie przewag komparatywnych USA w eksporcie wybranych surowców roślinnych na Jednolity Rynek Europejski (JRE) na tle największych unijnych producentów i eksporterów analizowanych grup produktów w latach 2003-2017. W badaniach wykorzystano dane pochodzące z zasobów Konferencji Narodów Zjednoczonych ds. Handlu i Rozwoju (UNCTAD). W analizie przewag komparatywnych zastosowano wybrane wskaźniki ujawnionych przewag komparatywnych (XRCA, MRCA, RTA), wskaźnik pokrycia importu eksportem (CR), wskaźnik specjalizacji eksportowej (SI) indeks handlu wewnątrzgałęziowego Grubela-Lloyda (IIT) oraz udziały w eksporcie. Na podstawie przeprowadzonych analiz można stwierdzić, że USA generowały wysokie przewagi komparatywne w eksporcie na JRE owoców i orzechów oraz surowców oleistych, które zapewniały im znacząca, odpowiednio prawie 25procentową i ponad 15-procentową część ogółu przychodów z tytułu eksportu artykułów rolnożywnościowych do państw UE.
\end{abstract}

Słowa kluczowe: konkurencyjność, przewagi komparatywne, surowce roślinne, owoce i orzechy, nasiona i owoce oleistych, USA, Jednolity Rynek Europejski

\begin{abstract}
The aim of the paper was to assess the US comparative advantages in the export of selected plant raw materials to the Single European Market (SEM) against the major EU producers and exporters of analysed product groups in 2003-2017. The research is based on the data from the United Nations Conference on Trade and Development (UNCTAD) resources. The following indicators were used in the comparative advantage analysis: the Revealed Comparative Advantage Indexes (XRCA, MRCA, RTA), the Coverage Ratio (CR), the Specialization Indicator (SI), Intra-Industry Trade Index (IIT) and the export shares. It was proved that the US had strong comparative advantages in the export of fruits and nuts, as well as oil seeds and oleaginous fruits to the SEM. These product groups gave the US almost $25 \%$ and more than $15 \%$ of the total revenue from the export of agri-food products to the EU countries, respectively.
\end{abstract}

Key words: competitiveness, comparative advantage, plant raw materials, fruits and nuts, oil seeds and oleaginous fruits, the US, Single European Market

JEL Classification: F14, Q17

${ }^{1}$ dr hab., prof. UPP, Katedra Ekonomii i Polityki Gospodarczej w Agrobiznesie, Wydział EkonomicznoSpołeczny, Uniwersytet Przyrodniczy w Poznaniu, ul. Wojska Polskiego 28, 60-637 Poznań, e-mail: pawlak@up.poznan.pl; https://orcid.org/0000-0002-5441-6381

${ }^{2}$ mgr, Katedra Ekonomii i Polityki Gospodarczej w Agrobiznesie, Wydział Ekonomiczno-Społeczny, Uniwersytet Przyrodniczy w Poznaniu, ul. Wojska Polskiego 28,60-637 Poznań, e-mail: dawid.jabkowski@up.poznan.pl; https://orcid.org/0000-0002-8315-136X

${ }_{3}$ Artykuł współfinansowany przez Narodowe Centrum Nauki ze środków na naukę w ramach projektu badawczego z zakresu badań podstawowych OPUS nr 2015/17/B/HS4/00262, pt. Polski sektor rolnożywnościowy w warunkach implementacji Umowy o Transatlantyckim Partnerstwie Handlowym i Inwestycyjnym (TTIP). 


\section{Wprowadzenie}

Kraje UE i USA odgrywają istotną rolę w gospodarce światowej, a dla siebie nawzajem, mimo stosunkowo niewielkiej wartości bilateralnych obrotów artykułami rolnospożywczymi, są ważnymi partnerami gospodarczymi (zob. Czarny i Folfas, 2016). W 2017 roku wartość eksportu produktów rolno-żywnościowych z USA na rynki państw UE wyniosła niemal 12,3 mld USD, a kraje UE były piątym, co do wartości obrotów, odbiorca artykułów rolno-żywnościowych z USA ${ }^{4}$ (GATS, 2018). Jednocześnie produkty rolne zajmowały ważne miejsce w strukturze eksportu towarowego USA, generując około $10 \%$ wpływów z tytułu eksportu i zapewniając producentom rolnym około 20-25\% przychodów z produkcji rolniczej (Pawlak, 2011). Dla państw UE, charakteryzujących się wysokim stopniem koncentracji obrotów wewnątrzregionalnych, USA były pierwszym partnerem handlowym spośród krajów pozaunijnych (GATS, 2018). W 2017 roku z rynku amerykańskiego pochodziło ponad $11 \%$ ogółu żywności nabywanej przez państwa UE w krajach trzecich, a wśród importowanych produktów dominowały artykuły pochodzenia roślinnego oraz przetwory spożywcze, które łącznie stanowiły około 85\% wartości przywozu z USA do UE (Pawlak, 2017a).

Przez 50 lat od zakończenia II wojny światowej partnerstwo transatlantyckie służyło rozwojowi bilateralnej współpracy gospodarczej i wzmacnianiu międzynarodowej pozycji konkurencyjnej państw zlokalizowanych po obu stronach Atlantyku. Na początku XXI wieku ranga partnerstwa transatlantyckiego zaczęła się jednak obniżać, a coraz większe znaczenie ekonomiczne w relacjach z USA zyskiwały kraje Azji (zob. Kenen, 2004). Remedium na obserwowaną równocześnie utratę udziałów UE i USA w rynku światowym (Mucha-Leszko, 2018) oraz czynnikiem wspomagającym odbudowę transatlantyckich więzi gospodarczych miało być utworzenie strefy wolnego handlu UE-USA. Wyrazem dążeń do pogłębienia wzajemnych relacji gospodarczych UE z USA stały się negocjacje Transatlantyckiego Partnerstwa Handlowo-Inwestycyjnego (The Transatlantic Trade and Investment Partnership - TTIP), przerwane zmianą kierunku polityki zagranicznej USA w okresie prezydentury Donalda Trumpa. Z rozważań Kaufmann i Lohausa (2018) wynika jednak, że zarówno UE, jak i USA są gotowe do realizacji ambitnego i kompleksowego programu liberalizacji handlu i będą dążyć do zawarcia porozumienia. Takie stanowisko wydają się potwierdzać deklaracje składane w ostatnich miesiącach przez przedstawicieli administracji obu zainteresowanych stron. W tym kontekście pojawiają się pytania: $\mathrm{W}$ jakich warunkach i na jakich zasadach powinna przebiegać transatlantycka integracja powiązań gospodarczych? Jakie będą priorytety stron partnerstwa zarówno w odniesieniu do relacji bilateralnej, jak i w kwestiach globalnych? Czy przeciwstawne interesy i niestabilność polityki handlowej USA nie zantagonizują partnerów porozumienia? Uzgodnione ramy instytucjonalne współpracy, wraz z ilościową i jakościową zasobnością w czynniki produkcji, stosowanym systemem kierowania gospodarką, czynnikami strukturalnymi, techniczno-technologicznymi, koniunkturalnymi i politycznymi ${ }^{5}$, będą współdecydowały o możliwościach i sile oddziaływania gospodarek UE i USA na międzynarodowe otoczenie ekonomiczne oraz ich pozycji konkurencyjnej $\mathrm{w}$ gospodarce światowej i w relacji partnerskiej.

\footnotetext{
${ }^{4}$ Większych niż kraje UE zakupów żywności dokonywały na rynku amerykańskim jedynie Kanada, Meksyk, Chiny i Japonia.

${ }^{5}$ Zob. podział czynników konkurencyjności proponowany przez Sulmickiego (1977).
} 
W warunkach kształtowania nowej równowagi sił na rynku światowym, problematyka konkurencyjności międzynarodowej gospodarek UE i USA oraz ich poszczególnych sektorów nabiera szczególnego znaczenia. Specyficznym przedmiotem światowej wymiany handlowej są produkty rolno-żywnościowe. $\mathrm{Z}$ jednej strony, $\mathrm{z}$ uwagi na regionalnie odmienne warunki przyrodniczo-klimatyczne i glebowe oraz różnicę potencjałów produkcyjnych nie korelującą z liczbą ludności zamieszkującej poszczególne regiony świata, pojawia się bowiem potrzeba zagospodarowywania trwałych nadwyżek produkcyjnych, a z drugiej konieczność pokrywania niedoborów żywności i zaspokajania potrzeb rynku wewnętrznego przez uczestnictwo w handlu międzynarodowym (por. Wojciechowski, 1994). Nieodzowność wymiany żywności cechuje również relację handlową UE-USA, a kwestia konkurencyjności sektorów rolno-żywnościowych tych gospodarek jest poddawana analizom, zarówno w układzie bilateralnym, jak i na rynku globalnym. Badania poziomu i zmian przewag konkurencyjnych sektora rolnospożywczego krajów UE i USA w handlu światowym podejmowali m.in. Dunmore (1986), Reed i Marchant (1992), Gopinath i in. (1997), Rowiński i Bułkowska (2013), Nosecka i Pawlak (2014), Sapa (2014), Bojnec i Fertö (2015, 2017), Wijnands i Verhoog (2016) oraz Pawlak (2017b, 2018). Odnosząc się do partnerstwa transatlantyckiego, wobec różnicy skali produkcji i struktur produkcyjnych rolnictwa UE i USA oraz wynikających z niej przewag kosztowo-cenowych producentów i przetwórców z USA, częściej prowadzono dyskurs w kontekście rzeczywistej i potencjalnej konkurencyjności rolnictwa i przemysłu spożywczego krajów UE na rynku USA. Rzadziej natomiast poddawano dyskusji relację odwrotną. Stąd, biorąc pod uwagę strukturę asortymentową eksportu produktów rolnospożywczych z USA do państw UE oraz uwzględniając warunki konkurencji panujące w obrocie wewnątrzwspólnotowym, celem artykułu jest zidentyfikowanie przewag komparatywnych USA w eksporcie wybranych surowców roślinnych na Jednolity Rynek Europejski na tle największych unijnych producentów i eksporterów analizowanych grup produktów w latach 2003-2017.

\section{Dane i metody}

W badaniach wykorzystano dane pochodzące z zasobów Konferencji Narodów Zjednoczonych ds. Handlu i Rozwoju (United Nations Conference on Trade and Development - UNCTAD). Analizą objęto dwie grupy surowców pochodzenia roślinnego mające relatywnie największy, około 20-procentowy udział w strukturze eksportu produktów rolno-żywnościowych z USA do krajów UE, tj. owoce i orzechy oraz nasiona i owoce oleistych.

Szacunki przewag komparatywnych wykonano przy użyciu celowo dobranego zestawu ilościowych wskaźników międzynarodowej pozycji konkurencyjnej ex post, spośród których zastosowano wybrane wskaźniki ujawnionych przewag komparatywnych (XRCA, MRCA, RTA) ${ }^{6}$, wskaźnik pokrycia importu eksportem (CR), wskaźnik

\footnotetext{
${ }^{6}$ Wskaźniki ujawnionych przewag komparatywnych oceniono sumarycznie, wykorzystując występujące pomiędzy nimi zależności. Dodatnie wartości wskaźnika RTA i większe od jedności - XRCA świadczą o wysokiej konkurencyjności (+). Gdy wskaźnik RTA jest ujemny, a MRCA powyżej jedności badany kraj wykazuje brak konkurencyjności (-), natomiast w pozostałych przypadkach wyniki analizy nie są tak jednoznaczne $(+/-)$ (Frohberg, 2000).
} 
specjalizacji eksportowej (SI), indeks handlu wewnątrzgałęziowego Grubela-Lloyda (IIT) oraz udziały w eksporcie. Formuły obliczeniowe wskaźników w postaci ogólnej zostały odpowiednio zmodyfikowane i dostosowane do potrzeb analizy relacji bilateralnej ${ }^{\top}$.

Przewagi komparatywne generowane przez USA w eksporcie na Jednolity Rynek Europejski oceniono na tle głównych konkurentów na tym rynku, tj. największych unijnych producentów i eksporterów analizowanych grup produktów. W przypadku owoców i orzechów były to: Hiszpania, Polska, Francja, Grecja, Rumunia, Holandia, Włochy, Belgia i Niemcy, a w przypadku nasion i owoców oleistych: Francja, Rumunia, Niemcy, Węgry, Polska, Holandia i Bułgaria ${ }^{8}$.

Poprzedzającą analizę przewag komparatywnych charakterystykę eksportu produktów rolno-żywnościowych z USA do państw UE przeprowadzono na poziomie grup produktów wyodrębnionych według Międzynarodowej Standardowej Klasyfikacji Handlu (SITC). Zakres czasowy badań objął lata 2003-2017.

\section{Wartość i struktura eksportu produktów rolno-żywnościowych z USA na Jednolity Rynek Europejski w latach 2003-2017}

W latach 2003-2017 wartość eksportu produktów rolno-spożywczych z USA do państw UE zwiększyła się o ponad 70\%, osiągając w latach 2015-2017 przeciętnie 12,4 mld USD rocznie (tabela 1). Spośród podstawowych produktów rolnictwa w strukturze wywozu na Jednolity Rynek Europejski (JRE) dominowały owoce i orzechy oraz nasiona i owoce oleistych, które zapewniały USA od 33\% (lata 2003-2005) do 40\% (lata 2015-2017) całości przychodów z tytułu eksportu artykułów rolno-żywnościowych na rynki krajów UE. W latach 2015-2017 wartości eksportu tych dwóch grup asortymentowych wynosiły odpowiednio średnio 2,9 mld USD oraz 2,2 mld USD rocznie i były ponad 2-krotnie większe niż w okresie 2003-2005. Co istotne, udział obu grup produktów w strukturze eksportu rolno-spożywczego ogółem zwiększał się, odpowiednio z niespełna $14 \%$ do $17,5 \%$ oraz z $19,5 \%$ do ponad $23 \%$, m.in. kosztem napojów i tytoniu - trzeciej co do wartości wywozu grupy produktów odgrywającej istotne znaczenie w eksporcie z USA na JRE. Zarówno w wywozie owoców, jak i surowców oleistych USA uzyskiwały nadwyżkę obrotów z państwami UE. W okresie 2015-2017 dodatnie saldo w handlu owocami i orzechami przekraczało 2,7 mld USD rocznie, a w wymianie nasionami i owocami oleistych 2,0 mld USD. Łącznie nadwyżka bilansu handlowego generowana w zakresie tych dwóch grup asortymentowych o ponad 35\% poprawiała ujemne saldo obrotów rolnożywnościowych ogółem USA z UE ${ }^{9}$ (UNCTAD, 2018). Ponadto, z USA sprowadzano do krajów UE ryby i skorupiaki, warzywa, gotową paszę dla zwierząt oraz zboża i przetwory zbożowe. Można jednak zauważyć, że mimo wzrostu bezwzględnej wartości wywozu wymienionych grup produktów na JRE, wyłączając warzywa, ich udziały w eksporcie zmniejszały się, osiagając $\mathrm{w}$ ostatnim badanym trzyleciu odpowiednio około $9 \%, 8 \%, 6 \%$ i $4 \%$.

\footnotetext{
${ }^{7} \mathrm{Na}$ temat kryteriów doboru wskaźników, formuł obliczeniowych oraz zasad interpretacji wyników zob. m.in. Jagiełło (2003), Pawlak, Kołodziejczak i Kołodziejczak (2010), Pawlak (2013).

${ }^{8}$ Wśród wymienionych państw znajduje się pięciu największych producentów i eksporterów każdej analizowanej grupy produktów, wyłonionych odpowiednio na podstawie danych Eurostat i UNCTAD.

${ }_{9}^{9}$ W latach 2015-2017 deficyt handlu produktami rolno-spożywczymi USA z UE wynosił średnio 13,4 mld USD rocznie.
} 
Tabela 1. Wartość i struktura eksportu produktów rolno-żywnościowych z USA na JRE w latach 2003-2017 Table 1. Value and structure of agri-food export from the US to the Single European Market in 2003-2017

\begin{tabular}{|c|c|c|c|c|c|c|c|c|c|c|c|}
\hline \multirow{3}{*}{$\begin{array}{l}\text { Wyszczegól- } \\
\text { nienie }\end{array}$} & \multicolumn{6}{|c|}{ Eksport } & \multicolumn{5}{|c|}{ Struktura eksportu } \\
\hline & $\begin{array}{l}2003- \\
2005\end{array}$ & $\begin{array}{r}2006- \\
2008\end{array}$ & $\begin{array}{r}2009 \\
2011\end{array}$ & $\begin{array}{l}2012- \\
2014\end{array}$ & $\begin{array}{l}2015- \\
2017\end{array}$ & \multirow{2}{*}{$\begin{array}{l}2003- \\
2005 \\
=100\end{array}$} & \multirow[t]{2}{*}{$\begin{array}{l}2003- \\
2005\end{array}$} & \multirow[t]{2}{*}{$\begin{array}{l}2006- \\
2008\end{array}$} & \multirow{2}{*}{$\begin{array}{c}2009- \\
2011 \\
\%\end{array}$} & \multirow[t]{2}{*}{$\begin{array}{l}2012- \\
2014\end{array}$} & \multirow[t]{2}{*}{$\begin{array}{l}2015 \\
2017\end{array}$} \\
\hline & \multicolumn{5}{|c|}{ mln USD } & & & & & & \\
\hline $\begin{array}{l}\text { Zwierzęta } \\
\text { żywe }\end{array}$ & 188,7 & 260,0 & 181,0 & 204,0 & 199,6 & 105,8 & 2,6 & 2,8 & 2,0 & 1,7 & 1,6 \\
\hline $\begin{array}{l}\text { Mięso } \\
\text { i przetwory } \\
\text { mięsne }\end{array}$ & 253,5 & 294,0 & 356,3 & 384,6 & 310,8 & 122,6 & 3,5 & 3,1 & 3,9 & 3,1 & 2,5 \\
\hline $\begin{array}{l}\text { Produkty } \\
\text { mleczarskie }\end{array}$ & 50,4 & 122,6 & 110,2 & 95,6 & 57,8 & 114,8 & 0,7 & 1,3 & 1,2 & 0,8 & 0,5 \\
\hline $\begin{array}{l}\text { Ryby } \\
\text { i skorupiaki, } \\
\text { mięczaki } \\
\text { i pozostałe } \\
\text { bezkręgowce } \\
\text { wodne }\end{array}$ & 786,2 & 1088,5 & 1081,6 & 1192,9 & 1136,0 & 144,5 & 10,9 & 11,6 & 11,7 & 9,7 & 9,1 \\
\hline $\begin{array}{l}\text { Zboża } \\
\text { i przetwory } \\
\text { zbożowe }\end{array}$ & 496,6 & 908,7 & 612,9 & 638,9 & 508,6 & 102,4 & 6,9 & 9,7 & 6,6 & 5,2 & 4,1 \\
\hline $\begin{array}{l}\text { Nasiona } \\
\text { i owoce } \\
\text { oleistych }\end{array}$ & 1005,9 & 1307,0 & 1091,1 & 2007,3 & 2175,4 & 216,3 & 13,9 & 14,0 & 11,8 & 16,4 & 17,5 \\
\hline $\begin{array}{l}\text { Owoce } \\
\text { i orzechy }\end{array}$ & 1405,2 & 1776,4 & 1811,1 & 2588,6 & 2913,4 & 207,3 & 19,5 & 19,0 & 19,6 & 21,1 & 23,4 \\
\hline Warzywa & 452,2 & 612,5 & 710,1 & 904,9 & 1015,0 & 224,4 & 6,3 & 6,5 & 7,7 & 7,4 & 8,2 \\
\hline $\begin{array}{l}\text { Cukier } \\
\text { i wyroby } \\
\text { cukiernicze }\end{array}$ & 73,5 & 68,7 & 73,2 & 78,2 & 80,3 & 109,2 & 1,0 & 0,7 & 0,8 & 0,6 & 0,6 \\
\hline $\begin{array}{l}\text { Kawa, herbata, } \\
\text { kakao } \\
\text { i przyprawy }\end{array}$ & 89,1 & 100,7 & 116,8 & 132,5 & 177,8 & 199,6 & 1,2 & 1,1 & 1,3 & 1,1 & 1,4 \\
\hline $\begin{array}{l}\text { Pasza dla } \\
\text { zwierząt }\end{array}$ & 601,5 & 491,7 & 618,1 & 1016,1 & 703,4 & 116,9 & 8,3 & 5,3 & 6,7 & 8,3 & 5,7 \\
\hline $\begin{array}{l}\text { Oleje } \\
\text { i thuszcze }\end{array}$ & 8,3 & 44,0 & 100,2 & 83,1 & 129,9 & 1563,4 & 0,1 & 0,5 & 1,1 & 0,7 & 1,0 \\
\hline Napoje i tytoń & 1393,8 & 1579,1 & 1508,5 & 1754,7 & 1835,0 & 131,7 & 19,3 & 16,9 & 16,4 & 14,3 & 14,8 \\
\hline Pozostałe & 410,0 & 699,2 & 847,9 & 1170,9 & 1196,5 & 291,8 & 5,7 & 7,5 & 9,2 & 9,6 & 9,6 \\
\hline Ogółem & 7214,8 & 9353,2 & 9219,0 & 12252,4 & 12439,3 & 172,4 & 100,0 & 100,0 & 100,0 & 100,0 & 100,0 \\
\hline
\end{tabular}

Źródło: (UNCTAD, 2018), obliczenia własne. 
Z powyższego wynika, że państwa UE importowały z USA głównie produkty innych stref klimatycznych (np. owoce i orzechy), komplementarne względem wytwarzanych w UE lub produkowane $w$ ilościach niewystarczających względem potrzeb rynku wewnętrznego (nasiona i owoce oleistych), zajmując w relacji bilateralnej z USA pozycję ich importera netto. Taki stan rzeczy po pierwsze jest związany $\mathrm{z}$ obserwowanym od drugiej połowy lat osiemdziesiatych pogłębianiem specjalizacji eksportowej USA w zakresie produktów ogrodniczych (Sumner, 1995), a po drugie dowodzi słuszności spostrzeżeń Salvacruz i Reeda (1993) oraz Pawlak (2016), którzy wskazują, że w relacjach bilateralnych wartość eksportu z USA do państw ich partnerów handlowych jest uzależniona m.in. od poziomu samowystarczalności żywnościowej w krajach importerów oraz stopnia komplementarności rolnictwa partnerów handlowych.

\section{Przewagi komparatywne USA w eksporcie owoców i orzechów oraz surowców oleistych na Jednolity Rynek Europejski w latach 2003-2017}

Z przeprowadzonych analiz wynika, że w latach 2003-2017 USA posiadały silną pozycję konkurencyjną w eksporcie na JRE zarówno owoców i orzechów, jak i surowców oleistych (tabela 2 i 4). W handlu owocami i orzechami USA realizowały wyraźna specjalizację eksportową (SI>1) i uzyskiwały bardzo wysokie przewagi komparatywne (XRCA>1 i RTA>0), a najpoważniejszym spośród analizowanych państw konkurentem była dla USA Hiszpania. Należy jednak zaznaczyć, że o ile przywóz tej grupy produktów z USA w dużej mierze składał się z importu tzw. „pozostałych orzechów”, tj. migdałów, orzechów laskowych i włoskich oraz owoców suszonych, o tyle Hiszpania dostarczała na rynki pozostałych krajów UE głównie świeże owoce cytrusowe. W obu państwach udział owoców w eksporcie rolno-żywnościowym kierowanym na rynek wewnątrzunijny systematycznie zwiększał się. W okresie 2015-2017 przewyższał 22\% (tab. 3) i był około 3- lub 3,5-krotnie wyższy niż średnio w obrocie wewnątrzwspólnotowym $(2,95<\mathrm{SI}<3,83$; tab. 2). Wzrostowi znaczenia badanej grupy asortymentowej w strukturze eksportu na JRE towarzyszył wzrost przewag komparatywnych oraz rosnąca nadwyżka bilansu handlowego - początkowo większa w Hiszpanii niż w USA, ale już od 2009 roku świadcząca o umacniającej się pozycji konkurencyjnej eksporterów amerykańskich. W latach 2012-2017 wartość eksportu owoców i orzechów z USA do krajów UE około 14-krotnie przewyższała wartość importu tej grupy produktów, wskazując na stosunkowo małe zapotrzebowanie rynku amerykańskiego na produkty rolne strefy umiarkowanej, które z powodzeniem, a zwykle także taniej są wytwarzane w USA i które stanowią nadwyżki eksportowe tego kraju. Relatywnie niski stopień komplementarności oferty eksportowej państw UE i USA nadawał bilateralnej wymianie handlowej owcami i orzechami, pogłębiający się wraz z upływem czasu, charakter międzygałęziowy $(12,95 \%<$ IIT $<24,56 \%)$. Porównywalnie niska intensywność handlu wewnątrzgałęziowego charakteryzowała również hiszpańską wymianę wewnątrzwspólnotową, natomiast obroty owocami pozostałych analizowanych krajów odznaczały się wysokim stopniem nakładania się strumieni eksportu i importu, determinowanym bardziej komplementarną niż konkurencyjną strukturą produkcji i ofert eksportowych partnerów handlowych na JRE. 
Tabela 2. Konkurencyjność owoców i orzechów pochodzących z USA i wybranych państw członkowskich UE na JRE w latach 2003-2017

Table 2. Competitiveness of fruits and nuts exporting from the US and selected EU member states to the Single European Market in 2003-2017

\begin{tabular}{|c|c|c|c|c|c|c|c|c|c|c|c|}
\hline Wskaźniki & Lata & Belgia & Francja & Grecja & Hiszpania & Holandia & Niemcy & Polska & Rumunia & Włochy & USA \\
\hline \multirow{5}{*}{ SI } & 2003-2005 & 1,49 & 0,68 & 2,39 & 3,44 & 0,66 & 0,36 & 0,49 & 0,60 & 2,05 & 2,95 \\
\hline & 2006-2008 & 1,52 & 0,63 & 2,45 & 3,44 & 0,75 & 0,45 & 0,39 & 0,25 & 2,16 & 3,06 \\
\hline & 2009-2011 & 1,41 & 0,61 & 2,70 & 3,67 & 0,84 & 0,42 & 0,19 & 0,23 & 2,05 & 3,41 \\
\hline & $2012-2014$ & 1,26 & 0,58 & 2,57 & 3,83 & 0,96 & 0,41 & 0,21 & 0,26 & 1,93 & 3,69 \\
\hline & 2015-2017 & 1,13 & 0,56 & 2,30 & 3,55 & 1,05 & 0,47 & 0,24 & 0,16 & 1,77 & 3,64 \\
\hline \multirow{5}{*}{ CR (\%) } & \multicolumn{2}{|c|}{$2003-2005299,33$} & 89,90 & 269,09 & 1108,85 & 156,19 & 28,61 & 40,86 & 59,67 & 239,28 & 714,23 \\
\hline & \multicolumn{2}{|c|}{ 2006-2008 280,84 } & 81,78 & 281,91 & 936,17 & 205,95 & 40,36 & 41,00 & 15,35 & 293,67 & 780,33 \\
\hline & \multicolumn{2}{|c|}{$2009-2011265,61$} & 69,52 & 390,26 & 980,81 & 235,54 & 38,34 & 22,63 & 27,84 & 247,81 & 1023,21 \\
\hline & \multicolumn{2}{|c|}{$2012-2014207,63$} & 62,00 & 540,54 & 1173,20 & 268,00 & 36,41 & 30,76 & 20,76 & 229,15 & 1380,70 \\
\hline & \multicolumn{2}{|c|}{$2015-2017174,74$} & 48,21 & 610,98 & 1169,84 & 284,58 & 41,33 & 42,68 & 9,08 & 221,94 & 1444,59 \\
\hline \multirow{5}{*}{ XRCA } & 2003-2005 & 1,54 & 0,67 & 2,64 & 4,16 & 0,64 & 0,35 & 0,47 & 0,58 & 2,22 & 3,42 \\
\hline & 2006-2008 & 1,48 & 0,62 & 2,53 & 4,10 & 0,74 & 0,43 & 0,38 & 0,24 & 2,34 & 3,32 \\
\hline & 2009-2011 & 1,25 & 0,59 & 2,61 & 4,39 & 0,83 & 0,40 & 0,18 & 0,22 & 2,19 & 3,46 \\
\hline & $2012-2014$ & 1,10 & 0,57 & 2,44 & 4,63 & 0,95 & 0,40 & 0,20 & 0,25 & 2,05 & 3,79 \\
\hline & 2015-2017 & 1,10 & 0,54 & 2,45 & 4,30 & 1,06 & 0,46 & 0,23 & 0,15 & 1,87 & 4,33 \\
\hline \multirow{5}{*}{ MRCA } & 2003-2005 & 0,72 & 1,14 & 0,52 & 0,51 & 1,05 & 1,36 & 2,14 & 0,50 & 0,64 & 0,24 \\
\hline & 2006-2008 & 0,77 & 1,11 & 0,54 & 0,59 & 0,97 & 1,27 & 1,71 & 0,76 & 0,58 & 0,23 \\
\hline & 2009-2011 & 0,75 & 1,14 & 0,48 & 0,63 & 0,95 & 1,27 & 1,41 & 0,68 & 0,69 & 0,19 \\
\hline & $2012-2014$ & 0,82 & 1,16 & 0,37 & 0,62 & 0,85 & 1,28 & 1,29 & 1,13 & 0,71 & 0,16 \\
\hline & $2015-2017$ & 0,93 & 1,31 & 0,35 & 0,61 & 0,88 & 1,30 & 1,17 & 1,51 & 0,75 & 0,14 \\
\hline \multirow{5}{*}{ RTA } & $2003-2005$ & 0,82 & $-0,47$ & 2,12 & 3,65 & $-0,41$ & $-1,01$ & $-1,67$ & 0,08 & 1,57 & 3,19 \\
\hline & 2006-2008 & 0,71 & $-0,50$ & 1,99 & 3,50 & $-0,23$ & $-0,84$ & $-1,33$ & $-0,52$ & 1,76 & 3,09 \\
\hline & 2009-2011 & 0,51 & $-0,55$ & 2,13 & 3,76 & $-0,11$ & $-0,86$ & $-1,23$ & $-0,46$ & 1,51 & 3,26 \\
\hline & $2012-2014$ & 0,29 & $-0,59$ & 2,07 & 4,01 & 0,10 & $-0,88$ & $-1,09$ & $-0,88$ & 1,34 & 3,62 \\
\hline & 2015-2017 & 0,17 & $-0,77$ & 2,10 & 3,69 & 0,18 & $-0,84$ & $-0,95$ & $-1,36$ & 1,11 & 4,19 \\
\hline \multirow{5}{*}{$\begin{array}{l}\text { Ocena } \\
\text { sumaryczna }\end{array}$} & $2003-2005$ & + & - & + & + & - & - & - & $+/-$ & + & + \\
\hline & 2006-2008 & + & - & + & + & $+/-$ & - & - & $+/-$ & + & + \\
\hline & $2009-2011$ & + & - & + & + & $+/-$ & - & - & $+/-$ & + & + \\
\hline & 2012-2014 & + & - & + & + & $+/-$ & - & - & - & + & + \\
\hline & $2015-2017$ & + & - & + & + & + & - & - & - & + & + \\
\hline \multirow{5}{*}{ IIT (\%) } & 2003-2005 & 50,08 & 94,68 & 54,19 & 16,54 & 78,07 & 44,49 & 58,02 & 74,74 & 58,95 & 24,56 \\
\hline & 2006-2008 & 52,52 & 89,98 & 52,37 & 19,30 & 65,37 & 57,51 & 58,16 & 26,62 & 50,80 & 22,72 \\
\hline & 2009-2011 & 54,70 & 82,02 & 40,79 & 18,50 & 59,61 & 55,43 & 36,91 & 43,55 & 57,50 & 17,81 \\
\hline & $2012-2014$ & 65,01 & 76,55 & 31,22 & 15,71 & 54,35 & 53,38 & 47,04 & 34,38 & 60,76 & 13,51 \\
\hline & 2015-2017 & 72,79 & 65,06 & 28,13 & 15,75 & 52,01 & 58,49 & 59,83 & 16,65 & 62,12 & 12,95 \\
\hline
\end{tabular}

Źródło: (UNCTAD, 2018), obliczenia własne. 
Tabela 3. Udział owoców i orzechów w całkowitym eksporcie rolno-żywnościowym na JRE w latach 2003-2017 (\%)

Table 3. Share of fruits and nuts in the total value of agri-food export to the Single European Market in $2003-2017(\%)$

\begin{tabular}{l|rrrrr}
\hline \multicolumn{1}{c|}{ Kraje } & $2003-2005$ & $2006-2008$ & $2009-2011$ & $2012-2014$ & $2015-2017$ \\
\hline Belgia & 9,8 & 9,4 & 8,1 & 7,2 & 7,2 \\
Francja & 4,5 & 3,9 & 3,5 & 3,3 & 3,6 \\
Grecja & 15,8 & 15,2 & 15,6 & 14,7 & 14,8 \\
Hiszpania & 22,7 & 21,3 & 21,2 & 21,9 & 22,8 \\
Holandia & 4,3 & 4,7 & 4,9 & 5,5 & 6,8 \\
Niemcy & 2,4 & 2,8 & 2,4 & 2,4 & 3,0 \\
Polska & 3,2 & 2,4 & 1,1 & 1,2 & 1,5 \\
Rumunia & 3,9 & 1,6 & 1,3 & 1,5 & 1,0 \\
Włochy & 13,6 & 13,4 & 11,8 & 11,1 & 11,4 \\
USA & 19,5 & 19,0 & 19,6 & 21,1 & 23,4 \\
\hline
\end{tabular}

Źródło: (UNCTAD, 2018), obliczenia własne.

Wysokość przewag komparatywnych osiaganych przez badane państwa w wewnątrzwspólnotowym eksporcie owoców oraz saldo wymiany były widocznie skorelowane $\mathrm{z}$ poziomem realizowanej specjalizacji eksportowej. Wyższemu niż przeciętnie w skali UE znaczeniu analizowanej grupy asortymentowej w eksporcie (SI>1) towarzyszyły wyższe przewagi komparatywne (XRCA $>1$ i RTA $>0$ ) i nadwyżka bilansu handlowego (CR $>100 \%$; tab. 2). Ma to szczególne znaczenie dla Grecji, Włoch i Belgii, którym eksport owoców przysparzał zwykle co najmniej 10\% (w przypadku Grecji 15\%) całości przychodów $\mathrm{z}$ tytułu eksportu produktów rolno-żywnościowych na rynki pozostałych krajów UE i które stanowiły realne zagrożenie konkurencyjne dla części producentów i eksporterów z USA (tab. 3). Mniej korzystna niż państw z basenu Morza Sródziemnego była sytuacja konkurencyjna krajów strefy umiarkowanej, położonych w zachodniej i środkowo-wschodniej części Europy, o znacznym potencjale produkcyjnym, ale niepredysponowanych do całorocznej uprawy gatunków ciepłolubnych, a często także rozdrobnionej strukturze produkcji upraw ogrodniczych. Znajdowała ona odzwierciedlenie w niższym niż średnio w skali UE poziomie specjalizacji eksportowej $(\mathrm{SI}<0)$, braku przewag komparatywnych whandlu $(\mathrm{RTA}<0)$ oraz deficycie obrotów handlowych $(\mathrm{CR}<100 \%)$, wynikającym zwykle $\mathrm{z}$ wysokiej, wyższej niż w państwach Europy Południowej, intensywności handlu wewnątrzgałęziowego (IIT), z jednej strony wywołanej komplementarnym wobec partnerów handlowych w ramach UE charakterem struktury produkcji owoców, a z drugiej podobieństwem struktur popytu i rosnącymi wymaganiami konsumentów co do jakościowego i cenowego zróżnicowania oferowanych produktów (Pawlak, Kołodziejczak i Kołodziejczak, 2010).

Wyższe niż w eksporcie owoców, choć w analizowanym okresie malejące, były przewagi komparatywne uzyskiwane przez USA w wywozie na JRE surowców oleistych (tab. 4). Z uwagi na brak samowystarczalności żywnościowej w tym zakresie, UE od lat należy do największych importerów surowców oleistych na świecie, stosując w ich przywozie bardzo niskie stawki celne. Na rynki krajów UE sprowadza się je m.in. z USA, które w minionych kilkunastu latach generowały rosnące nadwyżki produkcji nasion oleistych względem krajowego zużycia (FAOSTAT, 2018). Przeznaczenie nadwyżkowych ilości na eksport sprawiało, że udział omawianej grupy asortymentowej w całkowitym eksporcie produktów rolno-żywnościowych z USA na JRE był od około 7 do 15 razy wyższy 
Tabela 4. Konkurencyjność nasion i owoców oleistych pochodzących z USA i wybranych państw członkowskich UE na JRE w latach 2003-2017

Table 4. Competitiveness of oil seeds and oleaginous fruits exporting from the US and selected EU member states to the Single European Market in 2003-2017

\begin{tabular}{|c|c|c|c|c|c|c|c|c|c|}
\hline Wskaźniki & Lata & Bułgaria & Francja & Holandia & Niemcy & Polska & Rumunia & Wegry & USA \\
\hline \multirow{5}{*}{ SI } & 2003-2005 & 8,05 & 2,07 & 1,11 & 0,51 & 0,77 & 14,13 & 8,42 & 15,17 \\
\hline & 2006-2008 & 8,86 & 2,01 & 0,78 & 0,44 & 0,98 & 17,09 & 6,39 & 11,56 \\
\hline & 2009-2011 & 13,07 & 1,48 & 0,75 & 0,32 & 0,56 & 12,16 & 5,74 & 7,22 \\
\hline & $2012-2014$ & 10,73 & 1,31 & 0,97 & 0,23 & 0,88 & 8,97 & 4,17 & 8,61 \\
\hline & $2015-2017$ & 10,50 & 1,50 & 1,02 & 0,27 & 0,73 & 14,35 & 4,27 & 10,89 \\
\hline \multirow{5}{*}{ CR (\%) } & 2003-2005 & 741,72 & 931,58 & 204,86 & 28,24 & 196,93 & 1113,87 & 1491,04 & 41746,55 \\
\hline & 2006-2008 & 705,76 & 672,99 & 102,08 & 22,75 & 241,21 & 450,02 & 1036,04 & 69664,88 \\
\hline & 2009-2011 & 1552,08 & 297,84 & 99,78 & 18,28 & 107,41 & 313,34 & 1220,89 & 37496,86 \\
\hline & 2012-2014 & 805,60 & 316,38 & 174,33 & 10,72 & 286,24 & 424,68 & 326,60 & 13754,73 \\
\hline & $2015-2017$ & 441,73 & 246,19 & 203,30 & 11,04 & 135,34 & 810,43 & 291,43 & 6633,02 \\
\hline \multirow{5}{*}{ XRCA } & 2003-2005 & 8,61 & 2,09 & 1,11 & 0,51 & 0,77 & 16,05 & 9,03 & 17,41 \\
\hline & 2006-2008 & 9,78 & 2,03 & 0,77 & 0,44 & 0,98 & 21,18 & 6,83 & 13,23 \\
\hline & 2009-2011 & 16,29 & 1,49 & 0,75 & 0,32 & 0,56 & 14,88 & 6,22 & 8,03 \\
\hline & $2012-2014$ & 13,09 & 1,31 & 0,97 & 0,23 & 0,87 & 10,53 & 4,43 & 10,03 \\
\hline & 2015-2017 & 12,38 & 1,51 & 1,02 & 0,27 & 0,73 & 18,24 & 4,51 & 12,93 \\
\hline \multirow{5}{*}{ MRCA } & $2003-2005$ & 1,63 & 0,31 & 1,28 & 1,83 & 0,62 & 0,62 & 0,89 & 0,02 \\
\hline & 2006-2008 & 1,19 & 0,38 & 1,84 & 1,99 & 0,62 & 1,61 & 0,86 & 0,01 \\
\hline & 2009-2011 & 1,04 & 0,55 & 1,75 & 1,76 & 0,75 & 2,92 & 0,70 & 0,01 \\
\hline & 2012-2014 & 1,76 & 0,47 & 1,26 & 2,28 & 0,52 & 1,77 & 2,26 & 0,04 \\
\hline & $2015-2017$ & 2,86 & 0,57 & 1,02 & 2,36 & 0,94 & 1,26 & 2,09 & 0,08 \\
\hline \multirow{5}{*}{ RTA } & 2003-2005 & 6,98 & 1,77 & $-0,17$ & $-1,32$ & 0,15 & 15,43 & 8,14 & 17,39 \\
\hline & 2006-2008 & 8,60 & 1,65 & $-1,07$ & $-1,55$ & 0,36 & 19,56 & 5,97 & 13,22 \\
\hline & 2009-2011 & 15,24 & 0,94 & $-1,00$ & $-1,44$ & $-0,19$ & 11,96 & 5,52 & 8,02 \\
\hline & 2012-2014 & 11,33 & 0,85 & $-0,29$ & $-2,06$ & 0,35 & 8,76 & 2,17 & 9,99 \\
\hline & $2015-2017$ & 9,52 & 0,94 & 0,01 & $-2,09$ & $-0,22$ & 16,97 & 2,42 & 12,85 \\
\hline \multirow{5}{*}{$\begin{array}{l}\text { Ocena } \\
\text { sumaryczna }\end{array}$} & 2003-2005 & + & + & - & - & $+/-$ & + & + & + \\
\hline & 2006-2008 & + & + & - & - & $+/-$ & + & + & + \\
\hline & 2009-2011 & + & + & - & - & $+/-$ & + & + & + \\
\hline & 2012-2014 & + & + & - & - & $+/-$ & + & + & + \\
\hline & $2015-2017$ & + & + & + & - & $+/-$ & + & + & + \\
\hline \multirow{5}{*}{ IIT (\%) } & 2003-2005 & 23,76 & 19,39 & 65,60 & 44,04 & 67,36 & 16,48 & 12,57 & 0,48 \\
\hline & 2006-2008 & 24,82 & 25,87 & 98,97 & 37,06 & 58,62 & 36,36 & 17,60 & 0,29 \\
\hline & 2009-2011 & 12,11 & 50,27 & 99,89 & 30,92 & 96,43 & 48,39 & 15,14 & 0,53 \\
\hline & $2012-2014$ & 22,08 & 48,03 & 72,90 & 19,37 & 51,78 & 38,12 & 46,88 & 1,44 \\
\hline & $2015-2017$ & 36,92 & 57,77 & 65,94 & 19,88 & 84,98 & 21,97 & 51,09 & 2,97 \\
\hline
\end{tabular}

Źródło: (UNCTAD, 2018), obliczenia własne. 
Tabela 5. Udział nasion i owoców oleistych w całkowitym eksporcie rolno-żywnościowym na JRE w latach 2003 $2017(\%)$

Table 5. Share of oil seeds and oleaginous fruits in the toal value of agri-food export to the Single European Market in 2003-2017 (\%)

\begin{tabular}{l|rrrrr}
\hline \multicolumn{1}{c|}{ Kraje } & $2003-2005$ & $2006-2008$ & $2009-2011$ & $2012-2014$ & $2015-2017$ \\
\hline Bułgaria & 7,3 & 10,5 & 21,0 & 19,5 & 16,5 \\
Francja & 1,9 & 2,4 & 2,4 & 2,4 & 2,4 \\
Holandia & 1,0 & 0,9 & 1,2 & 1,8 & 1,6 \\
Niemcy & 0,5 & 0,5 & 0,5 & 0,4 & 0,4 \\
Polska & 0,7 & 1,2 & 0,9 & 1,6 & 1,2 \\
Rumunia & 12,8 & 20,2 & 19,6 & 16,3 & 22,6 \\
Węry & 7,6 & 7,6 & 9,2 & 7,6 & 6,7 \\
USA & 13,9 & 14,0 & 11,8 & 16,4 & 17,5 \\
\hline
\end{tabular}

Źródło: (UNCTAD, 2018), obliczenia własne.

niż w państwach UE $(7,22<\mathrm{SI}<15,17)$. Zbliżony do USA poziom specjalizacji w eksporcie surowców oleistych realizowały wśród wybranych krajów jedynie Rumunia i Bułgaria, wiodący unijni producenci słonecznika, zyskując jednak przy tym znacznie mniejszą nadwyżkę obrotów. W latach 2003-2017 wartość eksportu nasion i owoców oleistych (głównie soi) z USA do UE przewyższała wartość ich importu z państw UE na rynek amerykański od ponad 66 (lata 2015-2017) do niemal 700 razy (lata 2006-2008), podczas gdy w Rumunii i Bułgarii nadwyżka ta była odpowiednio co najwyżej 11- i 16-krotna (tab. 4). Tak wysoki stopień pokrycia importu eksportem wynikał w USA ze stricte międzygałęziowego charakteru wymiany surowców oleistych z krajami UE (IIT $\leq 2,97)$. W latach 2015-2017 wywóz tej grupy asortymentowej zapewniał Bułgarii, USA i Rumunii odpowiednio ponad $16 \%, 17 \%$ i $22 \%$ łącznych przychodów z tytułu eksportu artykułów rolno-spożywczych na JRE (tab. 5), a poziom osiaganych w eksporcie przewag komparatywnych (XRCA, RTA) był wprost proporcjonalny do udziałów w handlu. Mniejsze zagrożenie konkurencyjne na rynkach państw UE stwarzali dla eksporterów amerykańskich producenci nasion oleistych z Węgier, Francji i Polski. Za znikomą można natomiast uznać presję konkurencyjną wywieraną przez pozbawionych przewag komparatywnych producentów holenderskich i niemieckich, w większym stopniu skupionych na zaspokajaniu rosnących potrzeb rynków wewnętrznych ${ }^{10}$ niż podejmujących specjalizację w eksporcie.

\section{Podsumowanie}

Podsumowując przeprowadzone analizy można stwierdzić, że w latach 2013-2017 USA realizowały wysoki poziom specjalizacji eksportowej i generowały wysokie przewagi komparatywne w eksporcie na JRE owoców i orzechów oraz surowców oleistych, które zapewniały im znacząca, odpowiednio prawie 25 -procentową i ponad 15-procentową część ogółu przychodów z tytułu eksportu artykułów rolno-spożywczych na rynki państw UE. Były to grupy produktów, w zakresie których kraje UE nie osiągały samowystarczalności

${ }^{10} \mathrm{~W}$ związku z coraz większym wykorzystaniem surowców oleistych na cele niespożywcze, w tym m.in. do produkcji do produkcji biopaliw, smarów i płynów hydraulicznych oraz oleochemikaliów. Szerzej na temat niespożywczego wykorzystania nasion oleistych i olejów roślinnych zob. m.in. Zanetti, Monti i Berti (2013). 
żywnościowej, a ich import w dużej mierze miał charakter komplementarny względem produkcji wewnątrzregionalnej lub niezbędny dla zaspokojenia potrzeb rynku wewnętrznego. Z uwagi na konieczność uzupełniania niedoborów produkcji wewnętrznej, w imporcie obu grup asortymentowych obowiązywały stosunkowo niskie stawki celne, a gros przywozu odbywało się na warunkach bezcłowych ${ }^{11}$. Niewysoki poziom ochrony taryfowej rynku UE, a w przypadku surowców oleistych także wyjątkowo niski poziom protekcji pozataryfowej służyły wyrównywaniu instytucjonalnych warunków konkurowania podmiotów z USA z eksporterami wewnątrzunijnymi ${ }^{12}$. Z kolei znaczący potencjał produkcyjny w zakresie produktów deficytowych na JRE oraz wynikające ze skali produkcji przewagi kosztowo-cenowe zapewniały eksporterom amerykańskim pozycję wysokokonkurencyjnego, jednak - sądząc po strukturze rodzajowej wymiany i jej międzygałęziowej specyfice - nie stanowiącego dużego bezpośredniego zagrożenia dla unijnych producentów, eksportera netto obu analizowanych grup asortymentowych.

\section{Literatura}

Bojnec, Š., Fertö, I. (2015). Agri $\square$ Food Export Competitiveness in European Union Countries. Journal of Common Market Studies, 53(3), 476-492. DOI: 10.1111/jcms.12215.

Bojnec, Š., Fertö, I. (2017). The duration of global agri-food export competitiveness. British Food Journal, 119(6), 1378-1393. DOI: 10.1108/BFJ-07-2016-0302.

Czarny, E., Folfas, P. (2016). Unia Europejska i Stany Zjednoczone w globalnej produkcji i międzynarodowej współpracy gospodarczej a TTIP (The European Union and the United States in global production and international economic cooperation and the TTIP). W: E. Czarny, M. Słok-Wódkowska (red.) Partnerstwo Transatlantyckie. Wnioski dla Polski (The Transatlantic Partnership. Conclusions for Poland) (s. 31-46). Warszawa: PWE.

Dunmore, J. (1986). Competitiveness and Comparative Advantage of U.S. Agriculture. Paper presented at the 1986 "National Public Policy Education Conference", Denver, Colorado, 16 September 1986.

FAOSTAT, 2018. Food Balance Sheets. Pobrane 8 października 2018 z: http://www.fao.org/faostat/en/\#data.

Frohberg, K. (2000). Konkurencyjność polskiego rolnictwa (Competitiveness of Polish agriculture). W: E. Majewski, G. Dalton (red.) Strategiczne opcje dla polskiego sektora agrobiznesu w świetle analiz ekonomicznych (Strategic options for the Polish agribusiness sector in the light of economic analysis) (s. 224-242). Warszawa: SGGW.

Global Agricultural Trade System (GATS), 2018. Pobrane 6 października 2018 z: https://apps.fas.usda.gov/gats/ ExpressQuery1.aspx.

Gopinath, M., Arnade, C., Shane, M., Roe, T. (1997). Agricultural competitiveness: The case of the United States and major EU countries. Agricultural Economics, 16(2), 99-109. DOI: 10.1016/S0169-5150(97)00001-7.

Jagiełło, M. (2003). Wskaźniki międzynarodowej konkurencyjności gospodarki (Indicators of international competitiveness of the economy). Studia i materiały $\mathrm{Nr} 80$. Warszawa: IKCHZ.

Kaufmann, S., Lohaus, M. (2018). Ever closer or lost at sea? Scenarios for the future of transatlantic relations. Futures, 97, 18-25. DOI: 10.1016/j.futures.2017.04.007.

Kenen, P.B. (2004). Transatlantic relations and the global economy. The North American Journal of Economics and Finance, 15(2), 149-159. DOI: 10.1016/j.najef.2004.05.001.

Mucha-Leszko, B. (2018). Causes of the European Union's Decreasing Position in the Global Economy in 2000-2016. Scientific Journal WULS-SGGW Problems of World Agriculture, 18(1), 159-175. DOI: 10.22630/PRS.2018.18.1.15.

${ }^{11}$ W 2017 roku średnia stosowana stawka celna ad valorem w imporcie na JRE nasion i owoców oleistych wynosiła $1,1 \%$, a odsetek bezcłowych linii taryfowych sięgał blisko $75 \%$. W przywozie owoców i orzechów obowiązywało cło ad valorem w wysokości 5,9\%, a na warunkach bezcłowych realizowany był import niemal $20 \%$ linii taryfowych (WTO, 2018).

12 Rozbudowane instrumentarium polityki rolnej i handlowej UE i USA, w tym zwłaszcza trudniejsze do wyodrębnienia bariery pozataryfowe, są - obok potencjału produkcyjnego - jednym z ważniejszych czynników przesąadzających o poziomie przewag komparatywnych uzyskiwanych przez te kraje zarówno w relacji bilateralnej, jak i w handlu światowym. 
Nosecka, B., Pawlak, K. (2014). Wybrane problemy konkurencyjności sektora rolno-spożywczego w Polsce i Unii Europejskiej (Selected problems of the agri-food sector competitiveness in Poland and the EU). Raport PW 2011-2014, 125. Warszawa: IERiGŻ-PIB.

Pawlak, K. (2011). Rozwój handlu zagranicznego produktami rolnymi USA (Development of the US foreign trade in agricultural products). Zagadnienia Ekonomiki Rolnej, 3(328), 116-133.

Pawlak, K. (2013). Międzynarodowa zdolność konkurencyjna sektora rolno-spożywczego krajów Unii Europejskiej (International competitive capacity of the agri-food sector in the EU countries). Rozprawy Naukowe, 448. Poznań: Wydawnictwo Uniwersytetu Przyrodniczego w Poznaniu.

Pawlak, K. (2016). Handel zagraniczny produktami rolno-spożywczymi Polski z USA (Foreign trade in agri-food products between Poland and the US). Zeszyty Naukowe Uniwersytetu Ekonomicznego w Katowicach, seria Studia Ekonomiczne, 305, 30-42.

Pawlak, K. (2017a). Znaczenie wymiany bilateralnej w handlu zagranicznym produktami rolno-spożywczymi UE i USA (The importance of the bilateral turnover to the EU and the US foreign trade in agri-food products). ZN SGGW Problemy Rolnictwa Światowego, 17(2), 199-210. DOI: 10.22630/PRS.2017.17.2.39.

Pawlak, K. (2017b). Importance and Comparative Advantages of the EU and US Agri-food Sector in World Trade in 1995-2015. Scientific Journal WULS-SGGW Problems of World Agriculture, 17(4), 236-248. DOI: $10.22630 /$ PRS.2017.17.4.100.

Pawlak, K. (2018). Zdolność konkurencyjna przemysłu spożywczego krajów UE, USA i Kanady na rynku światowym (Competitive Capacity of the EU, the US and Canadian Food Industry on the World Market). ZN SGGW Problemy Rolnictwa Światowego, 18(3), 248-261. DOI: 10.22630/PRS.2018.18.3.83.

Pawlak, K., Kołodziejczak, M., Kołodziejczak, W. (2010). Konkurencyjność sektora rolno-spożywczego nowych krajów członkowskich UE w handlu wewnątrzwspólnotowym (Competitiveness of agri-food sector of the EU new member states in the intra-EU trade). Zagadnienia Ekonomiki Rolnej, 1(322), 126-142.

Reed, M.R., Marchant, M.A. (1992). The global competitiveness of the U.S. food processing industry. Northeastern Journal of Agricultural and Resource Economics, 21(1), 61-70. DOI: $10.1017 / \mathrm{S} 0899367 \mathrm{X} 00002531$.

Rowiński, J., Bułkowska M. (2013). Strategie i kierunki rozwoju rolnictwa europejskiego (2). Materiały do syntezy (Strategies and directions for the development of European agriculture (2). Materials for synthesis). Raport PW 2011-2014, 96. Warszawa: IERiGŻ-PIB.

Salvacruz, J., Reed, M. (1993). Identifying the Best Market Prospects for US Agricultural Exports. Agribusiness, 9(1), 29-41. DOI: 10.1002/1520-6297(199301)9:1<29::AID-AGR2720090104>3.0.CO;2-L.

Sapa, A. (2014), Handel rolno-żywnościowy regionalnych ugrupowań integracyjnych. Podobieństwa i różnice (Agri-food trade of regional integration groupings. Similarities and differences). Warszawa: PWN.

Sulmicki, P. (1977). Międzynarodowa wymiana gospodarcza (International economic exchange). Warszawa: PWE.

Sumner, D.A. (1995). Agricultural Trade Policy. Letting Markets Work. Washington D.C.: The AEI Press.

UNCTAD, 2018. Data Center. Pobrane 22 września 2018 z: http://unctadstat.unctad.org/wds/ReportFolders/ reportFolders.aspx?sCS ChosenLang=en.

Wijnands, J.H.M., Verhoog, D. (2016). Competitiveness of the EU food industry. Ex-post assessment of trade performance embedded in international economic theory. LEI Report 2016-018. Wageningen: LEI Wageningen UR (University \& Research centre).

Wojciechowski, H. (1994). Międzynarodowy rynek produktów żywnościowych (The international market for food products). Poznań: Wydawnictwo Akademii Ekonomicznej w Poznaniu.

WTO, 2018. WTO Tariff Download Facility. Pobrane 9 października 2018 z: http://tariffdata.wto.org/Reporters AndProducts.aspx

Zanetti, F., Monti, A., Berti M.T. (2013). Challenges and opportunities for new industrial oilseed crops in EU-27: a review. Industrial Crops and Products, 50, 580-595. DOI: 10.1016/j.indcrop.2013.08.030.

Do cytowania / For citation:

Pawlak K., Jabkowski D. (2018). Przewagi komparatywne USA w eksporcie wybranych surowców roślinnych na Jednolity Rynek Europejski. Problemy Rolnictwa Światowego, 18(4), 370-381; DOI: 10.22630/PRS.2018.18.4.126

Pawlak K., Jabkowski D. (2018). Comparative Advantages of the US in the Export of Selected Plant Raw Materials to the Single European Market (in Polish). Problems of World Agriculture, 18(4), 370-381; DOI: 10.22630/PRS.2018.18.4.126 